How the Virtues of an Interpreter Presuppose and Perfect Hermeneutics: The Case of Thomas Aquinas

By: Eugene F. Rogers Jr.

Rogers, E.F. (1996). How the Virtues of an Interpreter Presuppose and Perfect Hermeneutics: The Case of Thomas Aquinas. The Journal of Religion, 76(1), 64-81.

Made available courtesy of the University of Chicago Press: http://www.jstor.org/stable/1204286

***@ the University of Chicago Press. Reprinted with permission. No further reproduction is authorized without written permission from the University. This version of the document is not the version of record. Figures and/or pictures may be missing from this format of the document. $* * *$

\begin{abstract}
:
This essay enlists Thomas Aquinas to enrich a late twentieth-century retrieval of the literal reading of biblical narrative in the Christian tradition. It argues that the Summa theologiae can be read so that the sensus litteralis, far from promoting one predeterminate meaning for a text, promotes instead a certain ordered diversity of readings, and that the evaluation of readings belongs largely elsewhere than in hermeneutics. It opposes both those who seek such a single meaning and those who propose that anything goes. In short, it is the office of hermeneutics to promote an ordered diversity, of ethics to evaluate the results, and of providence to control the outcome. Or in other words, hermeneutics belongs to what Thomas calls craft, and right interpretation to grace, working both within the interpreter and without. If right interpretation involves grace (or, more personally, the Holy Spirit), then within the interpreter one may speak of virtue, and outside the interpreter one may speak of providence.
\end{abstract}

Keywords: Theology | Christianity | Thomas Aquinas | hermeneutics

\title{
Article:
}

This essay enlists Thomas Aquinas to enrich a late twentieth-century retrieval of the literal reading of biblical narrative in the Christian tradition. ${ }^{1}$ It argues that the Summa theologiae can be read so that the sensus litteralis, far from promoting one predeterminate meaning for a text, pro-motes instead a certain ordered diversity of readings, and that the evaluation of readings belongs largely elsewhere than in hermeneutics. ${ }^{2}$ It opposes both those who seek such a single meaning and those who propose that anything goes. In short, it is the office of hermeneutics to promote an ordered diversity, of ethics to evaluate the results, and of providence to control the outcome. Or in other words, hermeneutics belongs to what Thomas calls craft, and right interpretation to grace, working both within the interpreter and without. If right interpretation 
involves grace (or, more personally, the Holy Spirit), then within the interpreter one may speak of virtue, and outside the interpreter one may speak of providence.

Although the essay seeks Thomas's aid in addressing issues that he treats ex professo only in bits and in a very different context, nevertheless, several factors suit him eminently to contribute to the modern discussion, among them his commitment to a fourfold reading of scripture founded on the literal sense, his attention to the virtues, and his treatment of divine providence-not to mention his unique standing among the medievals not only for Catholics, but also for Protestants, Aristotelians, and Anglo-American ethicists after Alasdair MacIntyre.

\section{AN INTERPRETER'S LICENSE}

Thomas's official statement in the Summa comes at 1.1.10. (All quotations from him in this section originate there. $)^{3}$ It may seem at first glance to wed him to the author's intention as a control on the possible senses of a text that would presume to eliminate some readings a priori. For the spiritual sense with its subdivisions "is based on and presupposes [fundatur et supponit] the literal sense," and "the literal sense is that which the author intends." But so simple a reading sets up an opponent of straw. It turns out that Thomas's reflection on the literal sense leaves matters surprisingly underdetermined and that the author's intention functions in his hands more to promote diversity than to contain it. Consider the text:

That God is the author of holy Scripture should be acknowledged, and God has the power, not only of adapting words to convey meanings (which a human being also can do), but also of adapting the things themselves [ut non solum voces ad significandumac comodet... sed etiamr esi psas].I n every branch of knowledge words have meaning [vocess ignificent], but what is special here is that the things meant by the words also themselves mean something. That first meaning whereby the words signify things belongs to the sense [sensus] first mentioned, namely the historical or literal. That meaning, however, whereby the things signified by the words in their turn also signify other situations is called the spiritual sense, and it is based on and presupposes the literal sense.

... Now because the literal sense is that which the author intends, and the author of holy Scripture is God who comprehends everything all at once in God's understanding, it comes not amiss [none st inconveniens] as St. Augustine says in Confessions XII, if many meanings [pluress ensus]a represent even in the literal sense of one passage of Scripture. ${ }^{4}$

From the article as a whole we can pick out three distinguishable senses of "literal." They admit of distinction, but they do not command it; Thomas expects them generally and for the most part to fall together, and if he articulated the distinctions that I am going to make he would probably flag them as "quoad nos." We may call them intentional, narrative, and communal.

1. It is the intentional sense that functions in the body of the article and makes the argument run. "The literal sense is that which the author intends," Thomas writes, "and the author of holy 
Scripture is God." Note that no modern inspiration theory plays any part here; God counts as author primarily of states of affairs. Human authors like human agents generally always act as free secondary causes. Otto Pesch even finds it congenial to argue that the Middle Ages possessed the presuppositions to open a door to historical-critical exegesis and indeed that Thomas of-fered more of the backing that historical criticism would require than anyone before him. ${ }^{5}$

2. In the body of the article and in his answer to the second objection Thomas has recourse to a potentially second, distinct sense of "literal." He calls it "historical," and in the phrase "litteralisv el historicus" he makes the two frequent yokefellows. He glosses it with Augustine as occurring "whenever any matter is straightforwardly recorded-"cum aliquid simpli-citerp roponitur."Note that Thomas adverts only to the manner of the re-cording, if you will, to the record's genre, and not to its reference. "Cum aliquid simpliciterp roponitur" is quite different from was eigentlichg eschehen ist. It is not here but under the relation of divine and human causality that Thomas may hold the door open to historical criticism. Evidence that the literal sense covers more than "history" currently does comes when Thomas treats parables. Therefore it seems helpful to describe the literal sense as "narrative." It captures Thomas's own "cum aliquid simplici-terp roponitur. "6

3. Thomas uses "literal" in a potentially third way when he answers the article's first objection. Someone has objected that multiple senses in scripture would set up confusion. Thomas makes three points: Only the literal sense can found argument, only it can support the spiritual senses, and it therefore occasions no confusion. In order for those claims to stand, Thomas must have some notion like this in mind: The literal sense functions de facto as that which commands agreement. But not in a static way, since it is the same agreement that founds the spiritual senses' diver-sity. ${ }^{7}$ Two interlocking functions arise from the way that literal and spiri-tual senses relate: as that which commands agreement the literal sense serves stability; as that which founds and supports the spiritual senses it promotes the diversity that it is a purpose of this essay to explore. It is the requirement of commanding general agreement that leads me to call the third use "communal."

Here as elsewhere my analysis diverges from that of James Samuel Preus's excellent book From Shadow to Promise. ${ }^{9}$ Preus argues that it is through Thomas that, by the time of the Reformation, the literal sense becomes the captive rather than the teacher of the hierarchy. The turn to the church offers one way-namely, Cajetan's ${ }^{10}$-of filling the gaps that an underdetermining hermeneutics opens up, to which I shall be offering an alternative. Against a view such as Preus's one may point to the extent of the community Thomas appeals to. (Recall that it is agreement only on the literal sense that he needs; disagreement on the spiritual senses comes as no surprise.) So it is that when Thomas comes to expound the literal sense of the Old Law he always turns to what the Jews do, and it is from Maimonides that he has learned much of what he says. Thomas evidently has quite a wide body of agreement in mind-one that extends beyond the hierarchy at least as far as Jews and probably beyond. One wonders whether it might not be 
possible, on analogy with the natural knowledge of God's existence and the natural knowledge of God's law to characterize the literal sense as the "natural knowledge" of God's Word. Under those circumstances it is hard to imagine how Thomas could, in the literal sense, exclude the readings of Protestants, so that if Thomas's article on the senses of scripture had controlled Catholic thinking at the time of the Reformation, and not Cajetan's commentary on it, the disputes could not, as Pesch points out, have run the way they did. ${ }^{11}$

After all is said and done, Thomas's purely methodological considerations seem to exclude only conflict with the literal sense. Conflict with God's intention, as we shall explore in more detail, will prove hard to establish. Thomas says little to raise the question of human access to it. And conflict about what to read as the literal sense will prove hard to resolve. Furthermore, some literal senses are metaphorical, the third re-ply says, as when scripture speaks of God's arm, so that figuration does not confine itself to the spiritual level. Even figurative senses may qualify as literal-that is, intentional-in the mind of God. ${ }^{12}$ All that leaves a great many questions unanswered, and a great deal in hermeneutics underdetermined. Contrary to expectation, therefore, method carries readers almost no distance at all toward evaluating interpretations. More help comes elsewhere.

\section{A SAMPLE OF FIGURATIVE EXEGESIS}

In this section I consider a sample of Thomas's exegesis, a figurative reading of sacrificial ceremonies described in Numbers 19. It will show three things: (a) How it calls out, from a modern point of view, for critical evaluation, for much of it will strike modern readers as offensive. (b) How it, especially as inherited from the tradition and hence nearer the center than the margin of Thomas's practice, shows off a great open-ness to or range among figurative meanings, literal in the mind of God. (c) How, like the natural knowledge of God and the natural law, Thomas's hermeneutical theory follows and validates scripture-in this case Hebrews $13 .{ }^{13}$

A figurative reason for this sacrifice is that the red cow signified Christ in the lowly condition he took on himself, this being denoted by the sex of the animal, and its colour signified the blood of Christ's passion. The cow was of fullage, because all the works of Christ are perfect; it had no blemish, nor had it ever born the yoke, for Christ did not bear the yoke of sin. It was commanded to be brought to Moses, because to it was imputed the transgression of the Mosaic Law in the breach of the Sabbath. It was also commanded to be delivered over to Eleazer the priest, because Christ was delivered into the hands of the priests to be put to death. It was sacrificed outside the camp, because Christ suffered out-side the gate [Heb. 13:12]. The priest dipped his finger in the blood, because, by discernment, which the finger signifies, the mystery of Christ's passion is to be reflected and imitated. It was sprinkled over against the tabernacle, which de-noted the synagogue, either in condemnation of the unbelieving Jews, or to indi-cate the purification of believers. This was done seven times, either in token of the seven gifts of the Holy Spirit, or of the seven days in which all time is comprised. [1-11.102.5 ad 3] 
a) Some objections. This will probably strike many modern readers as "having gone too far." That any determinate meaning should attach to the number seven seems to ignore the variety of contexts in which it ap-pears: it might as well stand for the seven openings in the head. That the color of the heifer should signify Christ's passion recalls an accusation that gets used to dismiss all medieval exegesis: anything red stands for Christ's passion. That a finger dipped in blood should signify the finger of discernment seems to ignore that in the first case it would point down and in the second up. That the sprinkling of the blood should condemn the Jews sounds antiSemitic. And that the heifer's sex should symbolize Christ's lowly estate sounds (to use an anachronistic category) sexist.

b) On the other hand Thomas's method will give us no purchase against such readings. Nor should it. Any norms fine enough to exclude standard medieval procedures would end up also excluding many cur-rent procedures that it would impoverish modern interpreters to give up. Does it import a category any more foreign to the text for Thomas to see Christ's blood in something red than for a Freudian to see a phallus in something long? Is it any less arbitrary for Thomas to pair off seven sprinklings of blood with the seven gifts of the Spirit than for a structural-ist to pair off first and last, second and penultimate words of a text until she reaches its center? The Freudian and the structuralist could, like Thomas, each produce enough hermeneutics after the fact to defend the moves. How better could feminists defend the application of female im-ages to the second person incarnate than by invoking typology to argue that Numbers and Hebrews have, in the red heifer, given them authority and precedent? Or how better to counter nineteenth-century slavemasters' and contemporary bigots' appeals to the curse of Ham than to preach from verses in Revelation that describe the bronze skin and woolly hair of the last Judge? ${ }^{14}$

c) Thomas's interpretation goes only somewhat further than Hebrews. Any method that excluded some details a priori would run the risk of outlawing the biblical example. Therefore we may regard this as a positive function and purpose of Thomas's hermeneutics: that it make room for exegesis like that in Hebrews and reflect on it after the fact-that it make room, in fact, for the use of the Hebrew Scriptures by the New Testament authors. It is not, after all, as if Thomas had worked out a general hermeneutics before he had any samples of successful exegesis.

\section{AN ORDERED DIVERSITY: FITTING EXPLICATIONS AND SPIRITUAL SENSES}

Thomas heads the sample of exegesis we have been considering with the rubric "conveniens ratio," a fitting explication or suitable reason. ${ }^{15}$ Arguments from convenientia befit the realm of contingency rather than necessity. Perhaps a consistent use of sensus spiritualis in the theory and conveniens ratio in the example marks the usual gap between the divine and the human, the objective and the intersubjective. The sensus spiritualis is at home in God's mind, to which human beings in this life ordinarily lack access; the conveniens ratio underlines a theologian's humility before that lack-by contrast with a ratio necessaria, at home in a domain where hu-man minds (still fallible) may actually possess the principles from which they reason. ${ }^{16}$ Signal 
evidence for the distinction may be that convenientes rationes appear most prominently and elaborately when Thomas is explicating the mysteries of God's action in salvation history, especially the gracious contingencies in the commandments of the Torah and the life of Christ."

If I am right, what I have called "the usual gap" works to preserve an apophatic moment in Thomas and to name human ignorance, like this: In the five ways Thomas reaches conclusions about "what everyone calls God" (1.2.3). They conclude, that is, not with the apodictically indisputable but with what no one in fact disputes. Similarly on the natural knowledge of God's law Thomas appeals not directly to the eternal law beyond our grasp but to what "is the same for most people" (I-II.94.4). Again, he expects to prevent confusion by reference to the literal sense. At the same time human beings remain importantly blind to the realities to which they refer: the divine essence, the divine law, and the divine inten-tion lie in this life beyond human sight. Thomas's purpose in marking the gap is not to undermine the five ways or the natural law or the literal sense by contrast to something more objective, but to license appeal to what most people agree on by contrast to that to which human beings lack access. The five ways, the natural law, and the literal sense help ex-plain why Thomas saw a good deal of commonality, even transcultural commonality in interpretation, but human knowledge of the literal sense lacks the character that would enable it to settle disputes apodictically. ${ }^{18}$

So if a tendency to distinguish conveniens ratio from a spiritual sense objective to God but beyond human access furthers that distinction, then one might expect appeals to convenientia to pick out a communally agreed-on spiritual sense, while appeals to a sensus spiritualis pick out the sense intended by God using states of affairs to speak but to which human beings ordinarily lack any direct access. Thus Thomas would use conve-nientia positively, to commend the sense of the believing community in interpretation, as "what everyone calls God" commends in natural theology, "what is the same for most people" commends it in the theory of the natural law, and the literal sense as that which prevents confusion commends in a theory of the natural knowledge of God's Word. Thus the sensus as intended by God using things to speak, whether literal or figurative, provides a theological (rather than general hermeneutical) warrant for a ratio ex convenientia, a de jure answer to the question of why the community proves reluctant to give up a particular entrenched reading-as, for instance, when one part of the scriptures offers it for another part, just as eternal law provides a theological (rather than meta-ethical) answer to the question, Why natural law? and "God" tenders a theological answer to the question, What prime mover? ${ }^{19}$

In rare cases the appeal to the literal sense as God's intention will work to privilege some figurative readings, namely, when they show up as the literal sense of some other passage. In most cases, however, the label literal or God's intended sense will (because states of affairs may signify other states of affairs indefinitely) become a whole category into which many readings may fall. Thomas insists on that point when he writes, as we saw above, that "it comes not amiss [non est inconveniens] if many meanings are present even in the literal sense." As a whole 
category the appeal to author's intention promotes diversity rather than restriction of readings, particularly since we can point so rarely to relatively independent indications of what it is.

It will seem less strange that the author's intentions should function that way if one considers a similar change in "intention" after Freud. Without psychoanalytic theory the notion of "subconscious intention" sounds like a contradiction in terms. Yet post-Freudians have become so familiar with it that it gives them no second thought. So, too, Thomas's readers with multiple divine intention. A post-Freudian author with sub-conscious intentions may escape our grasp better than a pre-Freudian one without, just as a divine author resists human control better than a mortal one. One author's subconscious may arrange words to stand for states of affairs that stand for further, psychologically explicable states of affairs that the author may not acknowledge or may even disavow, just as another author's God may arrange divine words to stand for states of affairs that stand for other, christologically explicable states of affairs that the author, ante Christum natum, might want to disavow. ${ }^{20}$ So, in both cases the author's intention serves to expand rather than narrow the range of readings. Finally, parts of psychoanalytic theory distant from textual interpretation, such as the stages of sexual development, will tend to privilege some readings, just as parts of theology distant from hermeneutics, such as doctrines of the atonement, will tend to privilege some exegeses. But such theoretical contexts relate so distantly to official method as to constitute distinct interests and purposes.

In a moment I will go on to talk about how Thomas evaluates the interests and purposes of the interpreter. But first it is time to reexamine the first objection that Thomas poses to his own view. Is it not the case that the existence of multiple senses sub una littera takes away the "firmness of argument" (I.1.10 obj. 1)-especially if the multiplicity is that not merely of the spiritual senses, but that of the literal sense itself, as a class of meanings? The answer to the first objection assumes that Thomas directs it only against the possibility of spiritual senses. "The multiplicity of these senses does not make for equivocation," because it is the states of affairs rather than the words that support the spiritual senses. Firmness of argument is maintained, the reply continues, because in case of dispute, argument may proceed on the basis of the literal sense alone. The answer to the first objection appeals to the literal sense: it does not contemplate the possibility of the literal sense taking the firmness of argument away. That question remains unanswered: Granted that firmness of argument is maintained once the literal sense has been established, how is firmness of argument maintained in establishing the literal sense in the first place? Or, in other words: Suppose there is a dispute about the literal sense itself?

There are several answers. One is that Thomas is not a modern thinker and is not imagining "firmness of argument" with the architecture of a building in mind, where something would stand as a foundation. Earlier in the same question Thomas considers the scientific character of the discipline of theology using personal rather than architectonic metaphors-or better, it is the architect he mentions rather than the building. The student of sacred doctrine uses manuductions as an architect uses a con-tractor or the civil authority the military (I. 1.5 ad 2). The use of inferiors by superiors in this way involves firmness not of the materials but of character, or the 
virtue of prudence, to which I will shortly come. So too the determination of the literal sense requires firmness of argument, "arguendi firmitatem," where "argument" is literally the human act of arguing, rather than a syllogism on a page. Arguing is more a matter of rhetoric, or art, than hermeneutics, or technique. Elsewhere, Thomas goes so far as to require that the literal sense bear more than one reading in order to preserve the possibility of arguing with opponentshe requires that the literal sense form a class of reading precisely to sustain the firmness of argument. To do otherwise might expose the arguments of the faith to the opposite of firmness: ridicule. ${ }^{21}$

For in the De potentia (q.4, a. I, c., post init.) Thomas writes, following Augustine, that one should avoid subjecting the truth of the faith to ridicule ( $a b$ infidelibus veritasfidei irridetur) by holding that something belongs to the faith that has been shown to be false. (The case in question is Aristotelian and biblical views of creation.) Since it is also to be avoided that anyone should claim that scripture teaches something false, the "give" must come in interpretation. Thus it is also to be avoided

that anyone confine [cogere] scriptures o to one sense, that other senses be entirely excluded, that in themselves contain truth and are able to be adapted to scripture, preserving the way the words run [salval itteraec ircumstantia]; for this pertains to the dignity of divine scripture, that it contain many senses under one letter, in order that it may both in that way befit diverse intellects of human beings-that all may marvel that they are able to find in divine scripture the truth that they conceived by their minds-and by this also defend more easily against the infidels, since if anything which someone wants to understand out of sacred scripture appears to be false, recourse is possible to another of its [literal!] senses.... Whence all truth [omnisv eritas] which, preserving the way the words run, can be adapted [potest adaptari] to divine scripture, is its sense [or, "is a sense of it"]. ${ }^{22}$

Does this mean that anything goes for the literal sense? By no means. Does Thomas provide a procedure that the Enlightenment would recognize as a method for adjudicating these difficult cases? No. But the marshaling of scientific and literary evidence for interpretation does require the virtue of prudence, about which Thomas has much to say.

\section{IV.T HEOLOGICAL INT ERESTS AND PURPOSES}

It should come as no surprise when specific samples of exegesis also reflect relatively distant theological interests and purposes. Any rabbi could point out the distance between precritical Jewish and Christian exegesis of the common scriptures. Nor would it take Mary Daly to point out that Thomas's method need not make a cow's sex the symbol of Christ's lowly estate. It simply follows that when hermeneutics leaves interpretation underdetermined, as Thomas's wisely does and as any interesting hermeneutics must, other-Thomas would say, contingentinterests and purposes take over. In his case it is precisely the relevant theological interests and purposes-like making Christian sense of Numbers, validating He-brews, unifying the two 
Testaments, elaborating the atonement-that render a reading conveniens. It is convenientia that allows Thomas to attribute reasoning from effect to cause to the second person of the Trinity and convenientia that leads him to associate the second person with the eternal law. Figurative readings most apt to remain inconveniens will also refer to Christ. At the end I will say more about how a theological commitment to providence constitutes one of the most pervasive of those interests apparently distant from hermeneutics.

Thus Thomas would appreciate if he did not inspire Jeffrey Stout's comments on method: method (bad sense)-a self-sufficients et of rules for performings ome task; ... see hermeneutics (bad sense); perfectly captured in this sentence from Camus: "Quando $n$ n'ap as de caractdre, ilf aut biens e donneru nem ithode."

method(innocuous sense)-rules of thumb for performing some task; not a substitute for phronesis and tact. ${ }^{23}$

\section{AN INTERPRETER'S VIRTUES}

The reference to phronesis, prudence, points us in an important direction, to the role that the will plays in interpretation and the leverage that its role might provide for evaluation. For interpretation is a human act. Therefore Thomas might well evaluate it as he evaluates other human acts. The state of the will plays a crucial role in Thomas's evaluation of the act of faith and in the act of fulfilling the natural law. That he fails to advert to it, as far as I know, in the case of interpretation, can therefore have nothing to do with a concern for consistency. Rather the reverse. Consistency and, if we follow other examples, even adequacy would demand it. Nor can his reluctance have anything to do with a lack of re-sources. For whatever reason, Thomas tended largely to neglect the virtue language where evaluation finds itself most at home. Current readers, however, may deploy it.

Thomas prescribes evaluation of both the exterior and interior aspects of a human act, giving to the interior act absolute priority. The product he evaluates according to art, and the agent according to virtue: charity (1-11.57.1), justice (1-11.57.3 ad 2), prudence (I-II.57.4).24 In detail: The theoretical knowledge or method regards only the true and false (1-11.57.2 ad 3). The hermeneutics of I.1.10 stands first of all under that description. Art, techne, or skill about things to be made, counts as an intellectual virtue-virtue because it specifies the good of a product-but not a moral one. As the mere exerciser of skill, even the artisan, almost as skill's instrument or a product's mere sufficient cause, can get evaluated in technical terms: "So long as a geometrician demon-strates truth, it does not matter how he or she feels about it, whether joyful or angry; neither ... is it relevant to the artisan as artisan .... Art gives only the ability to act well" (111.57.3).

For the actuality of acting well, however, an agent needs moral virtue. Take as a striking example the case of "the demons [who] believe and tremble" (11-11.5.3, esp. ad 1 and 3). It 
marks the demons to command a keener intelligence and an abler skill than we do. The evidence of signs compels them to confess Jesus as Lord quite apart from a movement of their wills-as it cannot compel human beings. Thus the demons who believe and tremble complete, despite themselves, the exterior act of faith. But they use the knowledge ill, detesting rather than loving it. And the interior act, their greater art all unavailing, vitiates their knowledge. It is thus, for Thomas, that "the demons believe and tremble," and thus that faith as a product of an intellectual process comes to count for them as something bad, something that redounds to their discredit. So too for the use of art-of which Thomas specifies that "constructing ... a pas-sage of prose" (111.57.3 ad 3) constitutes an instance-"In order that one may make good use of art, one needs a good will, which is perfected by moral virtue" (1-11.57.3 ad 2). Elsewhere, Thomas does not hesitate to turn from evaluation of the product, such as a piece of knowledge or an act in accordance with natural law, to the evaluation of its status in the agent's will-he insists on it. Why not then here? He goes on: "For this reason Aristotle says that there is a virtue for art, namely, a moral virtue, inasmuch as good use of art requires a moral virtue. Clearly it is through justice, which gives aright will, that an artisan is set on doing faithful work" (ibid.).

When Thomas turns his attention to the use of an art he takes the skill as a means, the product as a tool toward some end like justice. It is the employment of an interpretation that now needs attention. In an important case, of course, the first use of an interpretation comes by the interpretation's author. For no one interprets without a mind to use; every interpretation befits some purpose. Indeed, for Thomas acts do not occur or make complete sense except in reference to end. When the analysis also of an interior act applies to interpretation and its use, evaluation according to art is by no means left behind, but new criteria open up that Thomas makes richer and more nuanced. His comments on the art of interpretation occupy a single article; to it one may add a few articles on the intellectual virtues. Those on the moral with the theological virtues, on the other hand, run for hundreds of pages.

If readers instruct their interests along Thomas's lines then they will attend not only to an interpretation's truth but also to its goodness, not only to its art and skill but also to its use and fruit. That also makes sense in terms of Thomas's own interests and purposes. For it looks as if it falls to method, by purpose and function, to promote diversity; to evaluate the products and choose among them, on the other hand, falls to ethical reflection.

Of course it is not in this life simply and identically the same to display the virtues of an art and to count the artist among the virtuous. One can make a rough-and-ready, penultimate distinction between them. This is not the place to rehearse Thomas's arguments for the virtues' unity. But the rough-and-ready distinction does break down. The courageous Nazi, ${ }^{25}$ in a standard example, simulates courage well enough for an observer provisionally to call it that but proves finally to mistake true courage for foolhardiness. The infidel-killing crusader, in another, "Christ is Lord" his battle cry, utters a homophone for something true of Christ, but betrays a notion of lordship altogether at odds with what a true inter pretation of that predicate would require.26 The Nazi counterfeits courage, and the crusader belies his faith. 
Another way of stating the thesis is that hermeneutics requires wisdom. Thomas elsewhere confirms and qualifies the claim. At 1.1.6 he asks whether sacred teaching in general counts as wisdom. Not only does hermeneutics fall under sacred teaching, but, as sacred scripture is the instrumental cause of sacred doctrine, it helps to constitute it. ${ }^{27}$ Our first look at how hermeneutics requires wisdom confined itself to a thoroughly Aristotelian move without clear Christian commitments. Here, however, we find that radically theological claims of a sort Aristotle would hardly recognize lying just below the surface. Thomas writes, "That person ... who considers simply the highest cause of the entire universe, namely God, is to be called supremely wise." Obviously, Thomas calls on the interpreter of the Bible to exhibit such wisdom by considering how God uses states of affairs to speak. In fact, so deeply do Thomas's theological interests and purposes there ramify through the article on scripture's multiple senses that a modern reader might well read it as belonging more properly to a meditation on providence than to one on method. As Thomas specifies in the Quodlibetal Questions, "Things are so ordered in their course that such a [spiritual] sense can be taken from them only [by] the one who governs things by providence, who is God alone" (Quod. 7.6.3c). And Thomas defines providence as the prudence of God (1.22.1). In interpretation the prudence of the interpreter attempts to reflect the prudence of God in arranging states of affairs to speak. It is, on Thomas's account, highly appropriate to expect the interpreter's interests and purposes to deepen and inform the interpretation, since, as Victor Preller puts it, "conformation of the mind to the intention of sacred scripture effects the conformation of the soul to the Second Person of the Trinity." ${ }^{28}$ It is also appropriate therefore to attend to those interests and purposes and to ask about their christoformity.

Thomas's position also respects the contributions of interpreters lacking, like all human beings, perfect wisdom or justice or charity. It is not the case that a turn to the interpreter will by a species of Donatism render the histories of Emmanuel Hirsch inaccurate or subject the theology of Paul Tillich to dismissal. Nor will it plead specially for the pious ruminations of the beautiful soul. The reply to the third objection in the article on wisdom specifies as well the situation of the interpreter:

There are two kinds of wisdom.... Persons who possess the habit of a virtue rightly commit themselves to what should be done in consonance with it, because they are already in sympathy with it; hence Aristotle remarks that it is the virtuous person who sets the measure and standard for human acts. Alternatively,... per-sons soundly instructed in moral science can appreciate the activity of virtues they do not themselves possess.

The first way of judging divine things belongs to that wisdom which is classed among the Gifts of the Holy Ghost.... The second way of judging is taken by sacred doctrine to the extent that it can be gained by study. 
The passage offers two qualifications. First, it remains appropriate to find an interpretation or its application lacking in justice or charity even when readers appreciate those qualities more than they possess them. Justice and charity provide some of the categories that permit an approach to truth, that allow, in this case, the adequation of mind to text. ${ }^{29}$ Second, study remains of help. Both the ethical categories that Christian interpreters may want to bring to bear, and the hermeneutical skills that virtue and tradition have found helpful, will number among study's appropriate ends.

Suppose we return to Thomas's interpretation of Numbers and begin to treat it in the way I have suggested. At least two advantages accrue thereby. First, Christian interpreters will equip themselves better to do justice to the misgivings I sketched above. They will also give Thomas something more Thomistic to do with a reading that, like many others, he largely inherited. They will be able, for example, to defend the intu-ition that reading red as Christ's passion simply goes too far, the product of a runaway interpreter's appetite, the desire to interpret every detail: one needs the virtue of temperance to restrain it. ${ }^{30}$ Then they will be able, in a clearer case, to object to Thomas's use of the equation of the cow's sex with Christ's estate; he might more justly or hopefully have used it to say that estate of Christ elevated the sex of the cow. Then they will be able to help Thomas decide whether the sprinkling of blood against the tabernacle condemns the Jews or purifies the believers. ${ }^{31}$ Of course the change of ground will not end the debate but it may enrich it. For then Christian interpreters will also be arguing about how they, as authors and employers of texts, as well as how texts, as mines for typology, conform to Christ.

\section{BETWEEN PROVIDENCE AND PRAYER}

Those who worry about the use and abuse of texts, who fear that a glance at the interpreter gives the text "a wax nose," also tend if they follow the Enlightenment to address their worries in hermeneutics. How else, in other words, is the biblical text to offer resistance to interpreters' prejudices and preconceptions? Three points:

a) Thomas wastes little worry on "what the text says" as such. His hermeneutics devotes its two scant pages to pointing us elsewhere. Thomas worries less about what the text says, that is, than what God says through it. Even so, God speaks through it only secondarily, as the interpreter, or any human agent seeking to influence events works secondarily, since God's primary agency in revelation works through states of affairs, just as in general God's primary agency oversees all states of affairs in the world. So it is God and not the text-or God working through and with the text-that offers resistance.

b) It is certainly not the case that the Bible is for Thomas to leave interpreters' preconceptions unchanged. Neither, however, can it change them, in the absence of God's work in the will. If there were such a thing for Thomas Aquinas as secular biblical interpretation, it would differ from faithful biblical interpretation at the place where the eyes of faith see God's disposing of things. Thus, biblical hermeneutics, as Thomas accounts for it, requires a faith in divine 
providence that he expects only God to work. Furthermore, Thomas's subordination of biblical hermeneutics to general providence informs it in the farthest from an anthropocentric way. The influence the text may exert on the interpreter's interests and purposes also stands under providence. In short, providence names among other things a way in which for Thomas interpretation resists human attempts to control it.

c) Similarly, the influence that an interpreter's interpretation exerts on the way in which his or her purposes meet with success or failure stands under providence, too. The interpreter may never pursue an interest or purpose as though its success or failure depended alone on his or her own efforts. Such an attitude not only might lead to the sort of interpretation that fails to "do justice" to a text or that finds itself "untrue" to it; such an attitude also and definitely usurps God's place as the One Who employs states of affairs to speak. A recognition of the fact that the success or failure or unexpected use of an interpretation lies in God's hands places the interpreter under the obligation and grants the interpreter the freedom to do the next right thing in interpreting, without turning consequentialist about the result. And if the interpreter desires to influence the course of events more than the next right interpretation seems likely to do, a recognition of God's providential will reminds him or her that interpretation does not, after all, qualify as primary causality. Thomas makes prayer the highest of secondary causes, that is, the highest among human efforts. ${ }^{32}$

Those who worry about the salubrious or deleterious effects of interpretations will tend, if they follow the Enlightenment, to address their worries in hermeneutics. Those who worry about the effects of interpretation will tend, if they follow Thomas, to address their worries among other places in prayer. Prayer is in fact one of the aids to study and modes of acquiring scientia, along with imitation of the holy and the good, that Thomas recommends in a brief letter to a brother.33 It is therefore to prayer that Thomas would turn the interpreter who seeks to achieve some purpose by the most effective means. And the interpreter who prays well, of course, will find that prayer also improves the interpretation, most of all, perhaps, by leaving the interests and purposes that motivate it changed.

\section{Notes}

1 The essay hopes to contribute something to the work of Jeffrey Stout on the interpretation of texts in general, and to the work of Hans Frei and Kathryn Tanner to the study of the traditional sensus litteralis. By "literal reading," I have in mind what Frei describes in "The 'Literal Reading' of Biblical Narrative in the Christian Tradition: Does It Stretch or Will It Break?" in The Bible and the Narrative Tradition, ed. Frank McConnell (New York: Oxford University Press, 1986), pp. 36-77, and what Tanner describes in "Theology and the Plain Sense," in Scriptural Authority and Narrative Interpretation, ed. Garrett Green (Philadelphia: Fortress, 1987), pp. 59-78. Victor Preller's Divine Science and the Science of God: A Reformulation of Thomas Aquinas (Princeton, N.J.: Princeton University Press, 1967) lies in the background. 
2 Jeffrey Stout, "What Is the Meaning of a Text?" New Literary History 13 (1982): 1-12; in particular I owe the phrase "interests and purposes" to that article, and my attention to their ethical evaluation to conversations with Stout.

3 Compatible treatments occur at In Galatas 4, lectio 7 (on verse 4:24a, "which are said by allegory"), no. 254, and more extensively at QuaestionesQ uodlibetales, 7.6.1-3. I confine myself for the most part to the Summa because it has the advantage of also treating the virtues of human beings and the providence of God in the same work. It is also the last of the three. For a diachronic reading of Thomas's work, see Michel Corbin, Le chemin de la thdologie chez Thomas d'Aquin, Bibliotheque des archives de philosophie, nouvelle serie, 16 (Paris: Beauchesne, 1974).

4 I am using the Blackfriars' Latin-English edition of the Summa, gen. ed. Thomas Gilby, O.P. (New York: McGraw-Hill, and London: Eyre \& Spottiswoode, 1964-80), making minor changes without notice. In particular I will render "homo"b y "human being" and "se,"' sui," etc., by including both genders to which they tend to refer. Some comments on the standard Blackfriars' translation. The Latin prevents some mistakes that the English permits. Here for instance the word "meaning" can signify no unique, predeterminate sense of the sort that Wittgenstein complains of, for it represents two different nouns, "significatio"a nd "sen-sus," while at other times it abbreviates a verb. Thomas never says that "words convey mean-ings" in the sense that words count as one thing, things as a second thing, and meaning as a tertium quid; rather, he observes that we "accommodate" words to signify something. Thomas attends first of all, that is, to how people deploy words, rather than to what words mean in abstraction from use. In fact, as "voces" the "words" in question invoke the voice-they invoke, that is, instances of speech. And as "res" the "things" in question invoke not only physical objects but also entire situations or states of affairs. (Recall the res publica.) Thomas need therefore be saying nothing more theoretical than this: When we talk, we use words to some purpose; when God talks, God too does so to some purpose; but then it is first of all states of affairs rather than words that God deploys. That, by the way, renders biblical hermeneutics materially a meditation on providence, as we will come later to see in more detail.

5 "Unter den Denkvoraussetzungen des Mittelalters war dadurch das Tor zur philolog-ischen und historisch-kritischen Exegese geoeffnet. Hindurchzugehen war nicht mehr Sache des hi. Thomas. Aber mehr als alle vor ihm gab er denen die sachliche Rueckentdeck-ung, die spaeter hindurchzugehen hatten-bis heute." See Otto Hermann Pesch, "Exegese des Alten Testaments bei Thomas," in the DeutscheT homas-Ausgabe(H eidelberg: Graz, 1977), 13:701. The article as a whole also qualifies the assessment of Preus, below.

6 It was George Lindbeck who proposed to me, without noting the remark of I.1.10 ad 2, that "narrative" might capture the force of "sensusl itteralisv el historicus."A t In Sent., prol., art. 5, Thomas actually writes that "the mode of this science is narrative [narrativus]." I owe the 
reference to Marie-Dominique Chenu, La thtologie comme science au XIIIe siecle, 3d rev. ed. (Paris: J. Vrin, 1957), p. 66.

7 The characteristics requisite to such a sense seem to me entirely to agree with the analy-sis of Tanner, cited above.

8 See 11-11.1.8-10 on creeds and the church.

9 James Samuel Preus, From Shadow to Promise: Old Testament Interpretation from Augustine to the Young Luther (Cambridge, Mass.: Harvard University Press, 1969), pp. 46-60.

10 Printed after each article in the Leonine edition.

11 See Pesch, "Exegese," p. 701.

12 For discussion of the literature on that point, see Henri de Lubac, Exiggse midievale: Les quatres ens de l'dcriture( Paris: Aubier, 1964), 3, pt. 2:272-302, esp. p. 280.

13 For a long sample of Thomas's exegesis-an account of his commentary on Romans I-that does not much involve spiritual senses, see chaps. 3-6 in my Thomas Aquinas and Karl Barth: Sacred Doctrine and the Natural Knowledge of God (Notre Dame, Ind.: Notre Dame, in press). I am now at work on an article that seeks to understand the references to natural law in Thomas's commentary on Romans 1.

14 The curse of Ham: Gen. 9:22-25; bronze skin and woolly hair: Rev. 1:14-15, King James Version. For the use of the Revelation passage by American slaves, see Albert Rabo-teau, Slave Religion (New York: Oxford University Press, 1978).

15 It is tendentious of Blackfriars to translate "ratio" here as "the cause." The Latin and the context recommend the indefinite article. And "conveniens"in dicates contingency, whereas "cause" tends at least among modern readers to imply necessity.

16 I suspect the distinction between rationes convenientes and necessariae is not sharp but relative to accessibility of purposes or ends. Necessity belongs to the general, whereas the singulars of sacred doctrine are known in their necessity only by God; on the other hand, all human understanding of contingent things contains some element of necessity (I.86.3; for a technical discussion, see Preller [n. 1 above], pp. 80-87). The necessity of sacred doc-trine is in view of some purpose or end (cf. I.1.1 and 1.82.1, discussed in Corbin [n. 3 above], p. 695), in this case God's plan to admit human beings to the Trinitarian fellowship. The purpose or end of rocks, to give a different example, is to move toward the center of the earth, so that human beings know the necessities that make up physics as they know that tendency of rocks. But human beings can rarely claim to have such knowledge of God's purposes, or providence, as to assign necessity. Sacred doctrine is a science in the mind of God and the blessed, and it proceeds from their vision, or understanding shot through with necessity; but here below the adherents of 
sacred doctrine are not scientists, but believers (11-11.9.2), because their minds participate in the science's necessity only in part, by God's gracious revelation (1.12.13 ad 3). Indeed, to know God's purposes with necessity would be to know God's essence, since providence supplies a nominal definition of God (I. 13.9c), and God's essence remains "entirely unknown to human beings in this life" (In Rom. 1:19, no. 114; see 1.12.13 obj. I and ad 1).

17 Besides the exegesis of Numbers, see, e.g., question III.1, "De convenientia incarnationis."

18 That way of putting the claim owes much to a restatement of my point by George Lindbeck.

19 For more on the theological context of the Five Ways, see my Thomas Aquinas and Karl Barth, passim.

20 That is, to take a modern historicist view of how to read the counterfactual, what would a preChristian author make of a Christian hermeneutic? Thomas might answer it differ-ently. See 1111.2.7-8.

21 For my interpretation of how scripture functions in an Aristotelian and christological sense to supply the scientific character of sacred doctrine, see Thomas Aquinas and Karl Barth, chap. 2. See also Corbin, p. 717.

22 The Latin runs: ... ne aliquis ita scripturam ad unum sensum cogere velit, quod alios sensus qui in se veritatem continent, et possunt, salva cicumstantia litterae, scripturae aptari, penitus exclu-dantur; hoc enim ad dignitatem divinae scripturae pertinet, ut sub una littera multos sensus contineat, ut sic et diversis intellectibus hominum conveniat, ut unusquisque miretur se in divina scriptura posse invenire veritatem quam mente conceperit; et per hoc etiam contra infideles facilius defendatur, dum si aliquid, quod quique ex sacra scriptura velit intelligere, falsum apparuerit, ad alium eius sensum possit haberi recursus.... Unde omnis veritas quae, salva litterae cicumstantia, potest divinae scripturae aptari, est eius sensus. I owe the translation of "salva litteraec ircumstantia"to David Yeago. For discussion, see de Lubac, esp. pp. 283-85, and, more recently, Bruce Marshall, "Absorbing the World: Chris-tianity and the Universe of Truths," in Theologyi n Dialogue:E ssaysi n Conversationw ith George Lindbeck, ed. Bruce Marshall (Notre Dame, Ind.: Notre Dame University Press, 1990), pp. 69-102, esp. pp. 90-97. Note that de Lubac only objects to the formulation, adopted above, that spiritual senses are literal in the mind of God (n. 12 above, discussed at p. 280), when that claim is used in support of the further claim that the nonspiritual literal sense can have only one meaning, in contradiction to the passage in the De potentia. By the end of the discussion, de Lubac is also in favor of parsing the literal sense as a class of readings (pp. 284-85).

23 Jeffrey Stout, Ethics after Babel: The Languages of Morals and Their Discontents (Boston: Beacon, 1988), p. 296. This section also owes a great deal to Stout's "What Is the Meaning of a Text?" (n. 2 above). 
24 For more on the analysis of an act, see my Thomas Aquinas and Karl Barth, excursus to chap. 6; for more on prudence, see Daniel Nelson, The Priority of Prudence (State College:

Pennsylvania State University Press, 1990). Both works owe a great debt along these lines to Victor Preller.

25 See, e.g., Alasdair MacIntyre, After Virtue (Notre Dame, Ind.: Notre Dame University Press, 1981), pp. 167-68, reflecting a view he later abandoned.

26 See George Lindbeck, The Nature of Doctrine (Philadelphia: Fortress, 1984), p. 64; see also Bruce D. Marshall, "Aquinas as a Postliberal Theologian," Thomist 53 (1989): 353-402, esp. 362-64.

27 Doctrina, or teaching, is "the action of one who makes something known" (In post. anal. 1.1). Sacred doctrine is God's making known to human beings God's own self, and the temporal mission of the Person of Christ (1.43.2), to which human beings now have access in sacred scripture, "a created analogue of God's act of self-knowledge as expressed in [God's] Word or inner speech" (Preller [n. 1 above], pp. 232-33).

28 Preller, p. 233.

29 For a sketch of how for Thomas categorical relates to ontological truth, see Marshall, "Aquinas as a Postliberal Theologian" and the follow-up discussion in his "Thomas, Thomisms, and Truth," Thomist 56 (1992): 499-524.

30 The analysis could in this case also be confined to the intellectual virtue of wisdom, showing a lack of discernment about which details do and do not bear interpreting, but prudence, containing temperance, does relate to art at 11-11.57.5 esp. ad 3 in a way I take to permit this.

31 One need not attribute any intemperance, injustice, and so on, to Thomas himself, given the limitations of his time and his dependence on the tradition, but only to his inter-pretation. See the discussion of slaveholders' culpability in Stout, Ethics after Babel, pp. 83-87.

32 11-11.83.1-3, esp. 3 ad 3. 33 Epistola exhortatoriad e modos tudendia dfratrem Ioannem (in Opuscula theologica), no. 1223. I owe my attention to it to a suggestion by Otto Pesch. 